\title{
Maternal Caffeine Intake Has Minor Effects on Adenosine Receptor Ontogeny in the Rat Brain
}

\author{
ULRIKA ÅDÉN, ERIC HERLENIUS, LIE-QI TANG, AND BERTIL B. FREDHOLM \\ Department of Physiology and Pharmacology, Karolinska Institute, S-171 77, Stockholm, Sweden [U.A., \\ B.B.F.]; and Department of Woman and Child Health, Astrid Lindgren Childen's Hospital, S-171 76, \\ Stockholm, Sweden [U.A., E.H., L.-Q.T.]
}

\begin{abstract}
Maternal caffeine intake has been suggested to influence the offspring. We have studied the effects of maternal caffeine intake on adenosine and GABA receptors, targets for caffeine, during development of the rat brain. Caffeine $(0.3 \mathrm{~g} / \mathrm{L})$ was added to the drinking water of rat dams during pregnancy and early postnatal life. Adenosine $\mathrm{A}_{1}$ and $\mathrm{A}_{2 \mathrm{~A}}$ and $\mathrm{GABA}_{\mathrm{A}}$ receptor development was studied using receptor autoradiography and in situ hybridization. Pups were examined on embryonic d 14 (E14), E18, E21, $2 \mathrm{~h}$ after birth (P2h), P24h, postnatal d 3 (P3), P7, P14, and P21. Adenosine $\mathrm{A}_{1}$ receptor mRNA was detected at E14 and receptors at E18. $\mathrm{A}_{1}$ mRNA levels increased from the level reached at E18 between $\mathrm{P} 3$ and $\mathrm{P} 14$ (maximally a doubling), whereas $\mathrm{A}_{1}$ receptors, studied by $\left[{ }^{3} \mathrm{H}\right]-1,3$-dipropyl-8-cyclopentyl xanthine binding, increased later and to a much larger extent (about 10-fold) postnatally. Caffeine treatment had no significant effect on adenosine $A_{1}$ receptors or on $A_{1}$ receptor mRNA. $A_{2 A}$ mRNA had reached adult levels by E18, whereas receptor levels were low or undetectable before birth and increased dramatically until P14. Caffeine did not influence $\mathrm{A}_{2 \mathrm{~A}}$ receptors or $\mathrm{A}_{2 \mathrm{~A}}$ receptor mRNA
\end{abstract}

\section{ABSTRACT}

at any stage during development. [ $\left.{ }^{3} \mathrm{H}\right]$-flunitrazepam binding, representing $\mathrm{GABA}_{\mathrm{A}}$ receptors, showed large regional variations during ontogeny, but there were no clear differences between the caffeine-exposed and the nonexposed pups. Thus, exposure to a low dose of caffeine during gestation and postnatal life had only minor effects on development of adenosine $\mathrm{A}_{1}$ and $\mathrm{A}_{2 \mathrm{~A}}$ receptors and $\mathrm{GABA}_{\mathrm{A}}$ receptors in the rat brain. (Pediatr Res 48: 177-183, 2000)

\section{E, embryonic day}

\section{Abbreviations}

P, hours (h) or days after birth

DPCPX, 1,3-dipropyl-8-cyclopentyl xanthine

CGS 21680, 2-[ $p$-(2-carbonylethyl)phenylethylamino $]-5^{\prime}-\mathrm{N}-$ ethylcarboxamidoadenosine

SCH 58261, 5-amino-7-(2-phenylethyl)2-(2-furyl)-pyrazolo-

[4,3-e]-1,2, 4-triazolo[1,5-c]pyrimidine

R-PIA, R-N ${ }^{6}$-phenylisopropyladenosine

NECA, 5'-N-ethylcarboxamidoadenosine
Caffeine is the most widely consumed psychoactive substance. Whereas the use of alcohol and tobacco are usually limited during pregnancy, beverages containing caffeine are consumed at a normal or near normal rate (1). Negative effects on fertility and birthweight, risk for prematurity, and congenital malformations have been demonstrated in offspring of animals given high doses of caffeine (for review see Ref. 2), but there is no conclusive evidence that normal human consumption has teratological consequences. Epidemiologic studies have shown a dose-dependent reduction in birth weight when mothers consume more than seven cups of coffee a day $(3,4)$. Prenatal caffeine intake has been described to result in behavioral hyperactivity in developing rodents (5-7).

Received December 6, 1999; accepted January 18, 2000.

Correspondence to: Ulrika Ådén, Department of Physiology and Pharmacology, Karolinska Institute, S-171 77 Stockholm, Sweden.

The present study was supported by the Swedish Medical Research Council (project number 2553 to Bertil B. Fredholm and project number 5234 to Hugo Lagercrantz), the Institute for Scientific Information on Coffee, a Biomed II project funded by the European Commission, The Swedish Society for Medical Research, and by Karolinska Institutet.
The only known biochemical effect of caffeine in the brain in concentrations relevant to daily intake of coffee is blockade of adenosine $A_{1}$ and $A_{2 A}$ receptors (8). Both $A_{1}$ and $A_{2 A}$ receptors are present at birth in the rat $(9-11)$, but the major development in terms of density and coupling to second messenger-forming systems occurs postnatally $(12,13)$. Secondarily to actions on adenosine receptors there are effects on dopaminergic transmission (for review see Ref. 14, 15) and it is known that alterations in dopaminergic transmission may result in developmental changes (16). In addition, there is evidence that caffeine can directly and indirectly influence GABAergic neurotransmission $(8,15)$. Studies on the effects of methylxanthines on benzodiazepine receptors are contradictory. An increased number of benzodiazepine binding sites in the adult mouse brain after chronic administration of a high dose of caffeine has been reported $(17,18)$, but other investigators have shown no change at all (19, 20) or altered function of the receptor (21).

Caffeine given in doses similar to those resulting in longterm behavioral changes has been reported to alter the postnatal 
development of adenosine $A_{1}$ receptors (22-24). However, adaptive effects of low doses of caffeine have not been described. We have earlier shown that caffeine $(0.3 \mathrm{~g} / \mathrm{L})$ in the drinking water given to the rat dam during gestation and lactation produces plasma concentrations in the pups of $0.4-2$ $\mathrm{mg} / \mathrm{L}$ and that this treatment leads to reduced susceptibility to hypoxic brain ischemia on postnatal d 7 (25), a stage when the rat CNS maturity is thought to correspond to that of a near-term human fetus (for review see Ref. 26).

The present study was designed to examine the influence of chronic pre- and postnatal treatment with a dose of caffeine similar to that used by humans on development of adenosine $\mathrm{A}_{1}$ and $\mathrm{A}_{2 \mathrm{~A}}$ receptors and their corresponding mRNA as well as on benzodiazepine binding sites representing in the rat pup brain.

\section{METHODS}

Treatment. The experiments, which followed the European Community regulations, were approved by the regional animal ethics committee. Forty-four Wistar rats and their litters were used. Dams $(n=23)$ were given caffeine in the drinking water $(0.3 \mathrm{~g} / \mathrm{L})$, which was exchanged every third day to fresh solutions, from embryonic d (E) 2 throughout gestation and postnatal life. Twenty-one dams received ordinary tap water. The daily intake of water was measured in all litters. The day when a vaginal plug was found was designated E0. Rat brains were examined at E14, E18, E21, exactly $2 \mathrm{~h}$ and $24 \mathrm{~h}$ after vaginal delivery (P2h, P24h), and at postnatal d 3 (P3), P7, P14, and P21. From each treatment group 6 animals (from two different litters) were used for in situ hybridization and receptor binding studies.

Plasma concentrations of caffeine. Trunk blood from fifteen animals was collected in heparinized plastic tubes and centrifuged. Plasma concentrations of caffeine and its metabolites theophylline, theobromine, and paraxanthine were analyzed using high pressure liquid chromatography as described (27).

Sections. From embryos and pups up to P3, the whole head was collected, whereas in older animals, the brain was rapidly dissected out. Heads and brains were frozen on dry ice and stored at $-80^{\circ} \mathrm{C}$. Sagittal sections from the left hemisphere were cut on a Leitz cryostat. Sections were collected from the lateral part of olfactory bulb toward midline. For in situ hybridization, $14-\mu \mathrm{m}$ thick sections were thaw-mounted on poly-L-lysine $(50 \mu \mathrm{g} / \mathrm{mL})$ coated slides. For receptor autoradiography, $14-\mu \mathrm{m}$ thick sections were thaw-mounted on gelatin-coated slides. Specimens from different ages were processed in the same in situ hybridization and receptor binding runs to allow comparison of signals and binding density.

Receptor autoradiography. Receptor density was determined using receptor autoradiography with the adenosine $\mathrm{A}_{1}$ receptor antagonist $\left[{ }^{3} \mathrm{H}\right]$-1,3-dipropyl-8-cyclopentyl xanthine (DPCPX) $(0.5 \mathrm{nM})(28)$, the adenosine $\mathrm{A}_{2 \mathrm{~A}}$ receptor agonist $\left[{ }^{3} \mathrm{H}\right]$-2-[ $p$-(2-carbonylethyl)phenylethylamino]-5'-N-ethylcarboxamidoadenosine (CGS 21680) (2 nM) (29), the adenosine $\mathrm{A}_{2 \mathrm{~A}}$ receptor antagonist $\left[{ }^{3} \mathrm{H}\right]-5$-amino-7-(2-phenylethyl)2-(2furyl)-pyrazolo-[4,3-e]-1,2, 4-triazolo[1,5-c]pyrimidine $(\mathrm{SCH}$ 58261) $(0.2 \mathrm{nM})(30)$, and the $\mathrm{GABA}_{\mathrm{A}}$ receptor agonist $\left[{ }^{3} \mathrm{H}\right]-$
N-methyl-flunitrazepam (flunitrazepam) (1 nM) (20). Nonspecific binding was determined using R-PIA $(100 \mu \mathrm{M})$ (DPCPXbinding) and 2-chloroadenosine $(100 \mu \mathrm{M})$ (CGS 21680 binding), NECA (50 $\mu \mathrm{M})$ (SCH 58261 binding), and diazepam (5 $\mu \mathrm{M}$ ) (flunitrazepam binding). Ten-micrometer-thick sections were preincubated in $170 \mathrm{mM}$ Tris- $\mathrm{HCl}$ buffer containing $1 \mathrm{mM}$ EDTA and $2 \mathrm{U} / \mathrm{mL}$ adenosine deaminase at $37^{\circ}$ for 30 $\mathrm{min}$. Sections were then washed twice for $10 \mathrm{~min}$ at $23^{\circ}$ in 170 $\mathrm{mM}$ Tris- $\mathrm{HCl}$ buffer. Incubations were performed for $2 \mathrm{~h}$ at $23^{\circ}$ in $170 \mathrm{mM}$ Tris- $\mathrm{HCl}$ buffer containing DPCPX $(120 \mathrm{Ci} / \mathrm{mmol}$, $0.5 \mathrm{nM})$, CGS $21680(42.1 \mathrm{Ci} / \mathrm{mmol}, 2 \mathrm{nM})$, or SCH 58261 $(0.2 \mathrm{nM})$ and $2 \mathrm{U} / \mathrm{mL}$ adenosine deaminase. In the experiments with DPCPX, $1 \mathrm{mM} \mathrm{MgCl} 2$ was added to preincubation and to incubation buffer. The incubation with DPCPX was done in the presence of $100 \mu \mathrm{M}$ guanosine triphosphate (GTP) to convert all the receptors to the low-affinity state for agonists and thereby remove all endogenous adenosine (28). Sections were then washed twice for $5 \mathrm{~min}$ each in ice-cold Tris-HCl, dipped three times in ice-cold distilled water, and dried at $4^{\circ}$ over a strong fan. Slides were exposed to $\left[{ }^{3} \mathrm{H}\right]$-sensitive film with $\left[{ }^{3} \mathrm{H}\right]$ microscales for $4-8 \mathrm{wk}$. $\mathrm{GABA}_{\mathrm{A}}$ receptor density was determined using receptor autoradiography with flunitrazepam (1 $\mathrm{nM}$ ). Nonspecific binding was determined using diazepam (5 $\mu \mathrm{M})$. Ten-micrometer-thick sections were preincubated in 170 $\mathrm{mM}$ Tris-HCl buffer at $4^{\circ}$ for $30 \mathrm{~min}$. Incubation was performed for $1 \mathrm{~h}$ at $4^{\circ}$ in $170 \mathrm{mM}$ Tris- $\mathrm{HCl}$ buffer containing $\mathrm{N}$-methyl-flunitrazepam $(85 \mathrm{Ci} / \mathrm{mmol}, 1.0 \mathrm{nM})$. Sections were then washed twice for 1 min each in Tris- $\mathrm{HCl}$ at $4^{\circ}$, dipped in ice-cold distilled water, and dried at $4^{\circ}$ over a strong fan. Slides were exposed to $\left[{ }^{3} \mathrm{H}\right]$-sensitive film with $\left[{ }^{3} \mathrm{H}\right]$ microscales for 4-8 wk.

In situ hybridization. The 48-mer $\mathrm{A}_{1}$ adenosine receptor probe was complementary to nucleotides $985-1032$ of the rat $A_{1}$ receptor (31). The 44-mer $A_{2 A}$ probe was complementary to nucleotides 916-959 of the dog RDC8 cDNA (32). The adenosine receptor probes have been tested for specificity $(33,34)$. The oligodeoxyribonucleotides were radiolabeled using terminal deoxyribonucleotidyl transferase and $\left[{ }^{35} \mathrm{~S}\right]$ dATP to a specific activity of about $10^{9} \mathrm{cpm} / \mu \mathrm{g}$. Slide-mounted sections were hybridized in a cocktail containing $50 \%$ formamide, $4 \times \mathrm{SSC}, 1 \times$ Denhardt's solution, $1 \%$ sarcosyl, $0.02 \mathrm{M} \mathrm{NaPO}_{4}$ (pH 7.0), 10\% dextran sulfate, $0.06 \mathrm{M}$ dithiotreitol, $0.5 \mathrm{mg} / \mathrm{mL}$ sheared salmon sperm DNA, and $10^{7} \mathrm{cpm} / \mathrm{mL}$ of probe. After hybridization for $15 \mathrm{~h}$ at $42^{\circ}$, the sections were washed four times, $15 \mathrm{~min}$, in $1 \times \mathrm{SSC}$ at $55^{\circ}\left(\mathrm{A}_{1}\right.$ probe) or $45^{\circ}\left(\mathrm{A}_{2 \mathrm{~A}}\right.$ probe $)$, then dipped briefly in water and $70 \%, 95 \%$, and $99.5 \%$ ethanol, and air-dried. Finally, the sections were apposed to Hyperfilm $\beta$-max for 1-4 wk.

Drugs and chemicals. Caffeine was from Sigma Chemical Co. (St. Louis, MO, U.S.A.). $\left[{ }^{3} \mathrm{H}\right]$-DPCPX $(120 \mathrm{mCi} / \mathrm{mmol}$; 1,3-dipropyl-8-cyclopentyl xanthine) and [ $\left.{ }^{3} \mathrm{H}\right]$-CGS 21680 (42.6 Ci/mmol; 2-[p-(2-carboxy-ethyl)phenylethylamino]-5'$\mathrm{N}$-ethylcarboxamido adenosine) were from $\mathrm{New}$ England $\mathrm{Nu}-$ clear-DuPont (Stockholm, Sweden), $\left.{ }^{3} \mathrm{H}\right]-\mathrm{SCH} 58261$ (5amino-7-(2-phenylethyl)2-(2-furyl)-pyrazolo-[4,3-e]-1,2, 4-triazolo[1,5-c]pyrimidine) was a kind gift from ScheringPlough (Milan, Italy), and $\left[{ }^{3} \mathrm{H}\right]-\mathrm{N}$-methyl-flunitrazepam was from Amersham (Stockholm, Sweden). Adenosine deaminase 
and NECA were obtained from Boehringer Mannheim Scandinavia AB (Bromma, Sweden). The oligonucleotide probes were synthesized by Scandinavian Gene Systems (Köping, Sweden), $\left[{ }^{3} \mathrm{H}\right]$-film, terminal deoxyribonucleotidyl transferase, $\left[{ }^{35} \mathrm{~S}\right]$-dATP, Hyperfilm $\beta$-max, and $\left[{ }^{3} \mathrm{H}\right]$ microscales were from Amersham. R-PIA and 2-chloroadenosine were obtained from Sigma Chemical Co. (Stockholm, Sweden). Formamide was from Fluka (Buchs, Switzerland). All other chemicals were purchased from Merck (Spånga, Sweden).

Image analysis. Analysis of receptor expression and binding was performed using a computerized image analysis system (Imaging Research Systems, St Catherines, Ontario, Canada). Relative optic density of expression or binding was measured in autoradiograms and amounts of receptor-bound radioactivity of the specific brain regions were determined using $\left[{ }^{3} \mathrm{H}\right] \mathrm{mi}-$ croscale standards. Specific binding was calculated by subtraction of the OD values in sections where nonspecific binding was determined. Different regions of the brain in the prenatal rats were identified using the atlas by Altman and Bayer (35) and in postnatal rats using atlases by Sherwood and Timiras (36) and Paxinos and Watson (37).

Statistics. Results are given as mean \pm SEM. Weight and fecundity were compared between the groups using the $t$ test. Water intake was compared between caffeine and control group using the $t$ test and multivariate ANOVA, repeated measures design with Scheffe's F post hoc test using procedures in the JMP statistics package by SAS (Cary, NC, U.S.A.). The results from quantitative receptor autoradiography and in situ hybridization in each specific brain region were analyzed by two-way ANOVA (Graph Pad Prism; SYSTAT). All measurements were done on sections from 5 or 6 animals and each brain was treated as one observation by averaging density values of each region studied. Statistical hypotheses were considered significant if $p<0.05$.

\section{RESULTS}

Caffeine ingestion did not alter weight gain during first week of pregnancy $(20.5 \pm 0.9 \%$ in caffeine treated group and $19.0 \pm 0.9 \%$ in controls $)$, fecundity $(10.88 \pm 0.55$ pups and $10.91 \pm 0.59$ pups, respectively) or birth weight $(6.0 \pm 0.31 \mathrm{~g}$ and $5.5 \pm 0.22 \mathrm{~g}$, respectively). Litters that received caffeine drank more than control litters at all postnatal time points studied $(p<0.05)$, but differences were small $(1-8 \mathrm{~mL}$ per litter per day). The increased water intake in the caffeine group might be explained by the diuretic actions of xanthine adenosine antagonists (38). Plasma concentrations of caffeine and the metabolites theophylline, paraxanthine, and theobromine were measured on P7 and are presented in Table 1.

Table 1. Plasma concentrations of methylxanthines on P7

\begin{tabular}{ccc}
\hline $\begin{array}{c}\text { Methylxanthine }(\mathrm{mg} / \mathrm{L}) \\
\text { mean } \pm \mathrm{SEM}\end{array}$ & $\begin{array}{c}\text { Controls } \\
(\mathrm{n}=5)\end{array}$ & $\begin{array}{c}\text { Caffeine-treated group } \\
(\mathrm{n}=10) \\
(0.3 \mathrm{~g} / \mathrm{L})\end{array}$ \\
\hline Caffeine & $0.00 \pm 0.00$ & $0.85 \pm 0.04$ \\
Theophylline & $0.01 \pm 0.01$ & $0.04 \pm 0.019$ \\
Paraxanthine & $0.00 \pm 0.00$ & $0.09 \pm 0.07$ \\
Theobromine & $0.00 \pm 0.00$ & $0.01 \pm 0.01$ \\
\hline
\end{tabular}

\section{Adenosine $A_{1}$ Receptor mRNA and $\left[{ }^{3} H\right]$-DPCPX Binding}

We found that adenosine $A_{1}$ receptor mRNA was present on E14 in low levels in the neuroepithelium, in agreement with previous studies $(9,11)$, but we could not detect significant $\left[{ }^{3} \mathrm{H}\right]$-DPCPX binding until E18. On E18 both adenosine $\mathrm{A}_{1}$ receptor mRNA and $\left[{ }^{3} \mathrm{H}\right]$-DPCPX binding was present in most structures in the brain (Fig. 1). On E21, the distribution of $A_{1}$ mRNA, and DPCPX binding resembled that seen in the adult rat brain, but levels were lower (Figs. 1 and 2). There were no differences in adenosine receptors in the brains of pups decapitated shortly after vaginal delivery ( 2 or $24 \mathrm{~h}$ ) compared with levels on E21 (Fig. 2).

In the cerebral cortex, both $\mathrm{A}_{1}$ receptor mRNA and $\left[{ }^{3} \mathrm{H}\right]-$ DPCPX binding were detected on E18. Whereas mRNA levels were $40 \%$ of levels on P21, only a small amount of receptor protein was detected ( $8 \%$ of levels on P21). There was a clear elevation of both mRNA and receptor protein levels between P3 and P7 (Fig. 2). Caffeine-treated fetuses were found to have the same levels of both mRNA and receptor protein as controls. However at $24 \mathrm{~h}$ (P24h) and $7 \mathrm{~d}$ after birth (P7), $\left[{ }^{3} \mathrm{H}\right]$-DPCPX binding was significantly higher in caffeine-exposed pups than in controls $(31 \%, p=0.044$ and $15 \%, p=0.033$, respectively). $\mathrm{A}_{1}$ mRNA in caffeine group was not altered at any time point studied compared with controls.

In cerebellar cortex, the development of $\mathrm{A}_{1}$ receptors was clearly delayed compared with other regions. Both $\mathrm{A}_{1}$ mRNA
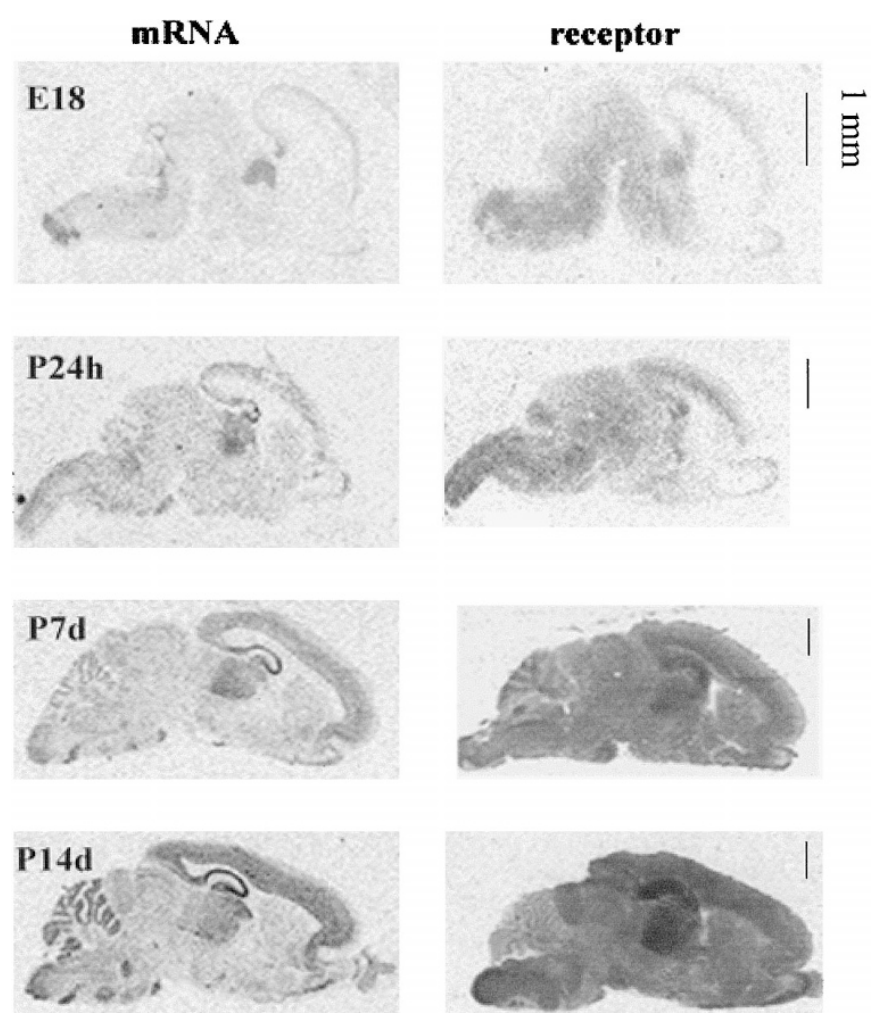

Figure 1. Film autoradiograms generated from in situ hybridization (left part) and receptor autoradiography (right part) showing adenosine $\mathrm{A}_{1}$ mRNA expression and $A_{1}$ receptor binding at different stages during early development: E18, P24h, P7, and P14. Sagittal sections are shown. In situ hybridization was performed using an oligonucleotide probe and receptor binding was determined using $\left[{ }^{3} \mathrm{H}\right]$-DPCPX-binding $(0.5 \mathrm{nM})$. Nonspecific binding was determined and was equal to background. 

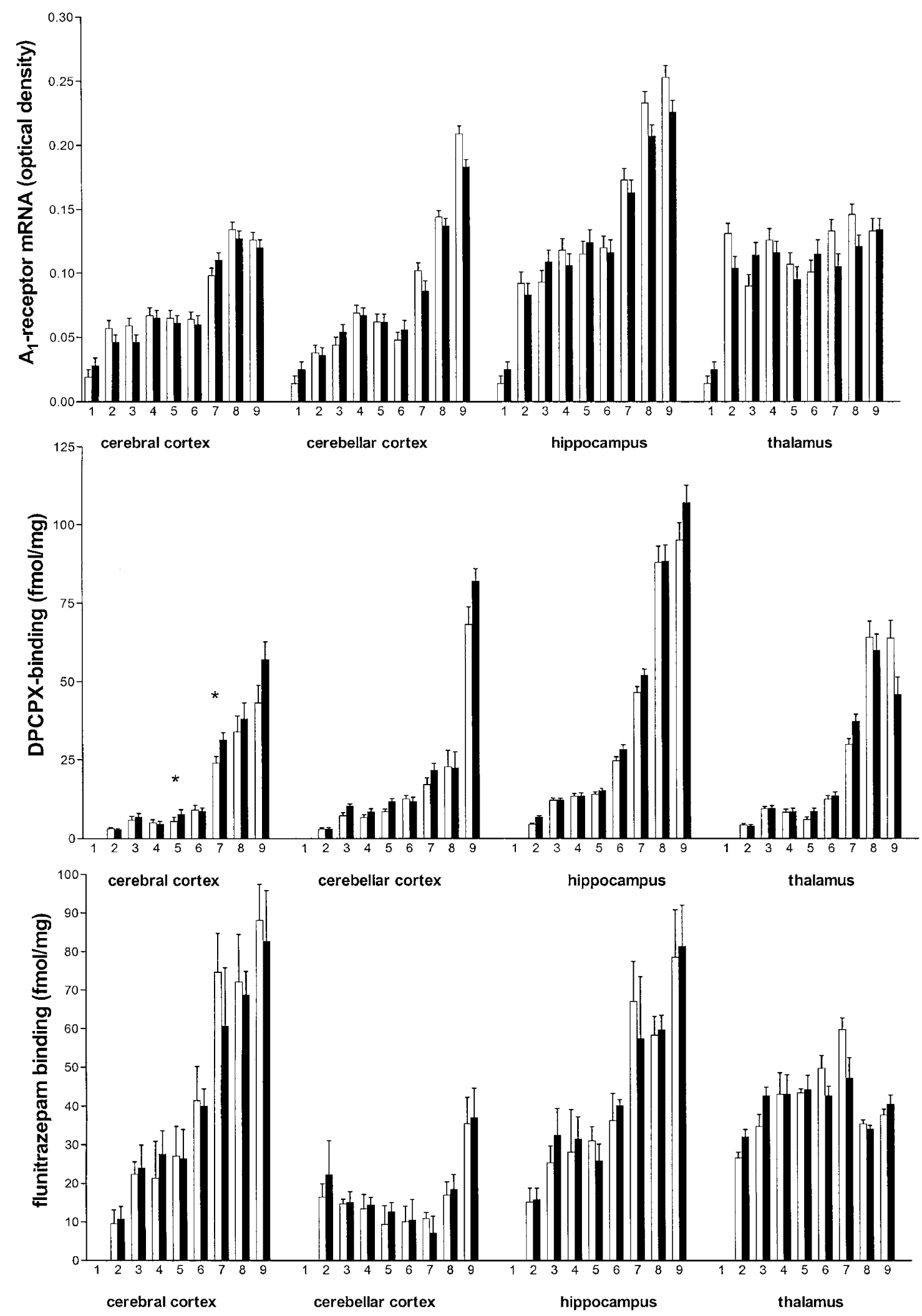

Figure 2. Regional pre- and early postnatal time course of adenosine $\mathrm{A}_{1}$ mRNA expression (upper panels), $\left[{ }^{3} \mathrm{H}\right]$-DPCPX binding (middle panels), and binding of $\left[{ }^{3} \mathrm{H}\right]$-flunitrazepam (lower panels) in the brain in controls (white bars) and low-dose caffeine-treated (black bars) rat fetuses $(1=\mathrm{E} 14,2=\mathrm{E} 18,3=\mathrm{E} 21)$ and pups $(4=\mathrm{P} 2 \mathrm{~h}, 5=\mathrm{P} 24 \mathrm{~h}, 6=\mathrm{P} 3,7=\mathrm{P} 7,8=\mathrm{P} 14$, and $9=\mathrm{P} 21)$. In cortex, measurements include all cortex layers; hippocampal measurements include CA1, CA3, and dentate gyrus. Measurements on E14 were not performed in each region, but represent a "whole brain" value. Mean and SEM of groups with $n=6 .{ }^{*}$ represents a $p$ value $<0.05$ when comparing controls and caffeine-treated pups. In all regions there was a highly significant $(p<0.001)$ age-related change for $\mathrm{A}_{1}$ mRNA expression, $\left[{ }^{3} \mathrm{H}\right]$-DPCPX binding, and $\left[{ }^{3} \mathrm{H}\right]$-flunitrazepam. 
and $\left[{ }^{3} \mathrm{H}\right]$-DPCPX binding could be detected on E18. The $\mathrm{A}_{1}$ mRNA was down-regulated on $\mathrm{P} 3$, but increased thereafter and the major development of receptor protein took place between P14 and P21 (Fig. 2). $A_{1}$ mRNA was found in the granular and Purkinje cell layer and $\left[{ }^{3} \mathrm{H}\right]$-DPCPX binding in the molecular cell layer, in agreement with previous studies (39), and this distribution was detected on P14. In the caffeine group, $\left[{ }^{3} \mathrm{H}\right]-$ DPCPX binding and $A_{1}$ mRNA was not altered at any specific time point studied, compared with controls.

$\mathrm{A}_{1}$ mRNA and $\left[{ }^{3} \mathrm{H}\right]$-DPCPX binding were higher in hippocampus than in all other regions at all time points studied (Fig. 2). Receptor protein increased earliest in this region, and on P7, the distribution of $\mathrm{A}_{1}$ mRNA and $\left[{ }^{3} \mathrm{H}\right]$-DPCPX binding in the hippocampus was qualitatively the same as in the oldest animals studied here. There were no statistically significant differences in $\left[{ }^{3} \mathrm{H}\right]$-DPCPX binding, but $\mathrm{A}_{1}$ mRNA levels were slightly lower in the caffeine-treated animals than in controls. A significant difference was observed if the data on P3-P21 were pooled ( $6 \%$ to $12 \%, p=0.009)$.

Total $\mathrm{A}_{1}$ mRNA amounts in thalamus reached adult levels already on E18, but the development of receptor binding had a time course similar to that in most $\mathrm{A}_{1}$ receptor-rich areas. No differences were seen between the caffeine-treated animals and controls.

\section{$A_{2 A}$ mRNA and Receptor Binding}

$\mathrm{A}_{2 \mathrm{~A}}$ mRNA was diffusely distributed all over the brain on E14 (not shown) in agreement with previous findings (10), but binding of the $\mathrm{A}_{2 \mathrm{~A}}$ receptor ligands $\left[{ }^{3} \mathrm{H}\right]-\mathrm{CGS} 21680$ and $\left[{ }^{3} \mathrm{H}\right]-\mathrm{SCH} 58261$ could not be detected at this stage. From E18 and onward, $\mathrm{A}_{2 \mathrm{~A}} \mathrm{mRNA}$ was expressed in the caudate putamen at relatively high levels (Fig. 3). $\left[{ }^{3} \mathrm{H}\right]$-CGS 21680 binding was present from E21 and $\left[{ }^{3} \mathrm{H}\right]-\mathrm{SCH} 58261$ binding was detected from P3 in the caudate putamen (Fig. 3) in low amounts and binding with both ligands increased mainly between P3 and

P3

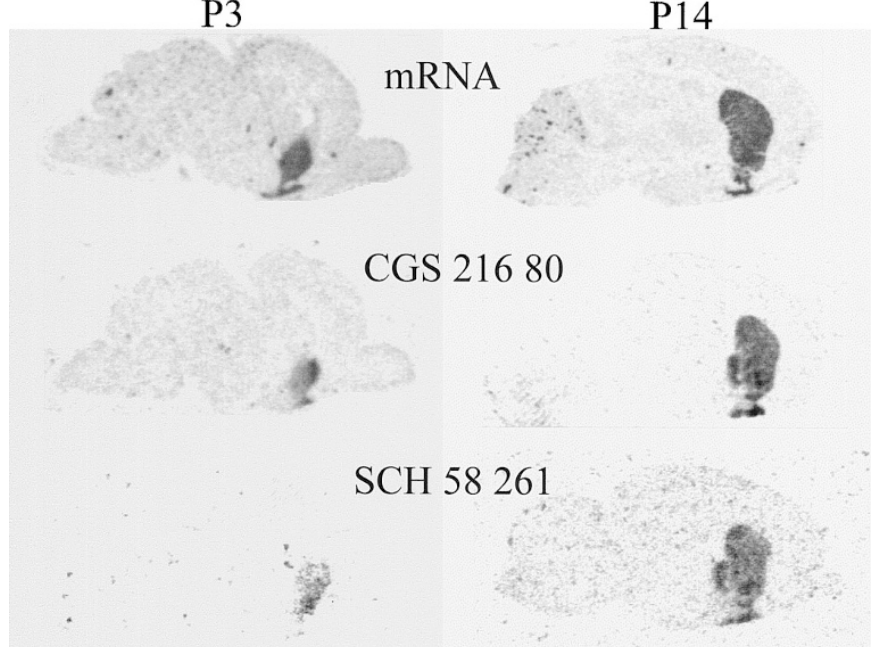

Figure 3. Film autoradiograms generated from in situ hybridization with an oligonucleotide probe (upper panels) and receptor autoradiography (with agonist $\left[{ }^{3} \mathrm{H}\right]-\mathrm{CGS} 21680,2 \mathrm{nM}$ (middle panel) or antagonist $\left[{ }^{3} \mathrm{H}\right]-\mathrm{SCH} 58261$, $0.2 \mathrm{nM}$ (lower panel)) showing adenosine $\mathrm{A}_{2 \mathrm{~A}}$ mRNA and receptors on P3 (left panels) and P14 (right panels). Nonspecific agonist and antagonist binding was determined and was in both cases equal to background.
P14 (Fig. 4). $A_{2 A}$ mRNA and receptor protein were also found in the olfactory tubercle (Fig. 3), but no measurements were made there.

Whereas previous studies on the effect of low doses of caffeine have not indicated any clear-cut effects on $\mathrm{A}_{1}$ receptors, recent results do show a decrease in $\mathrm{A}_{2 \mathrm{~A}}$ receptors and the corresponding mRNA, which is related to the known behavioral tolerance (40). There was no significant difference in development of $\mathrm{A}_{2 \mathrm{~A}}$ mRNA or receptor binding between pups subjected to caffeine treatment and controls, and there were no differences in adenosine $A_{2 A}$ receptors shortly after birth.

\section{GABA $_{\mathrm{A}}$ Receptor Binding}

The $\mathrm{GABA}_{\mathrm{A}}$ receptor ontogeny in different brain regions was studied using $\left[{ }^{3} \mathrm{H}\right]$-flunitrazepam binding and the results are shown in Fig. 2. As previously reported $(41),\left[{ }^{3} \mathrm{H}\right]-$ flunitrazepam binding sites could be detected on E14 in pons and medulla (not shown). Binding in cerebral cortex, cerebellar
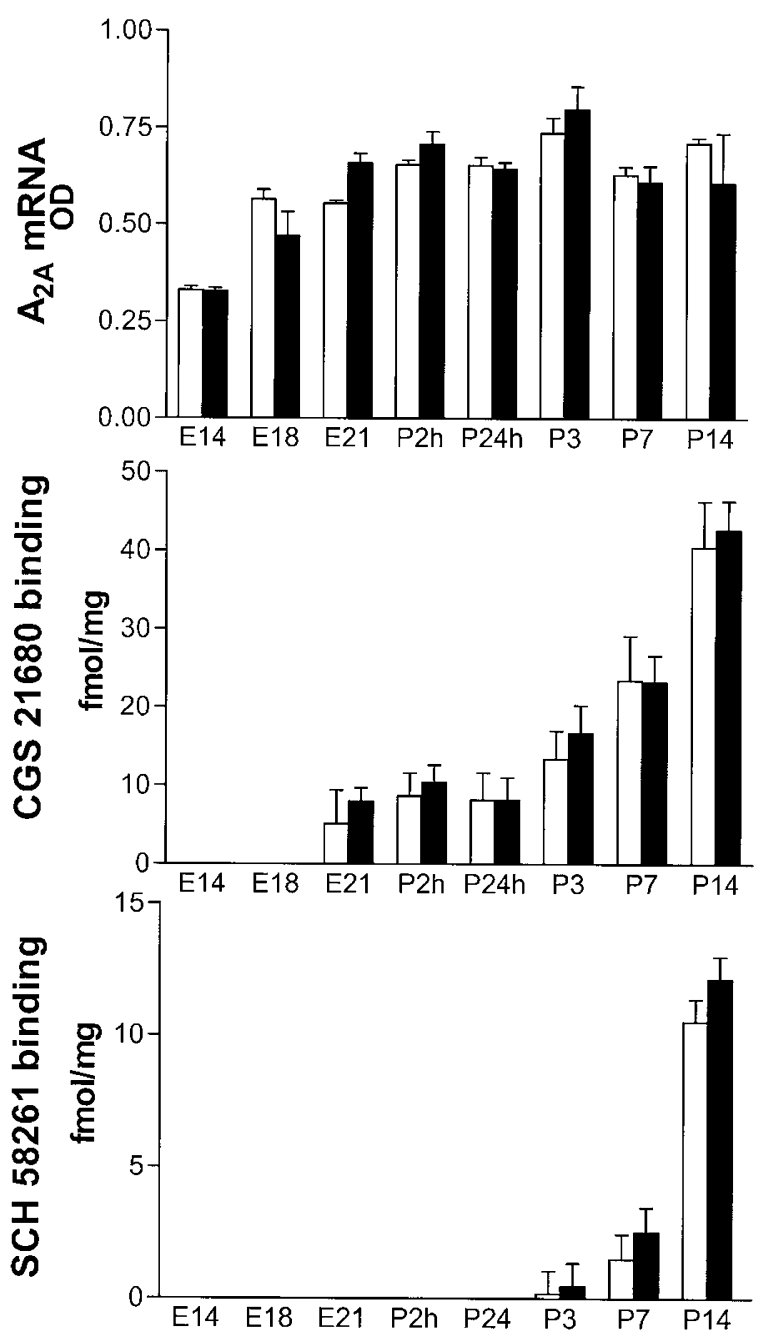

Figure 4. Adenosine $A_{2 A}$ mRNA expression (upper panel), agonist (middle panel), and antagonist (lower panel) binding to $\mathrm{A}_{2 \mathrm{~A}}$ receptors in caudate putamen during pre- and early postnatal development in controls (white bars) and caffeine-treated (black bars) fetuses and pups. All measurements made on consecutive sagittal sections. For further details see legend to Figure 3. Mean and SEM of groups with $n=6$. For each panel, there was a highly significant $(p<0.001)$ age-related change. 
cortex, hippocampus, and olfactory bulb was detected on E18 and in striatum on E21. There were no significant differences between controls and caffeine-treated animals at any specific time point or in any region.

\section{DISCUSSION}

The major finding of this study is that administration of caffeine in doses that resemble those consumed by humans does not significantly influence the development of receptors that are known or believed to be affected by this drug. These results are in apparent contrast to several previous studies mentioned at the beginning of this article, where caffeine has been reported to modify adenosine receptors and/or behavior.

A possible explanation is the difference in doses. For example, in neonatal pups who received $80 \mathrm{mg} / \mathrm{kg} / \mathrm{d}$ of caffeine, behavioral effects were observed (7). This dose is some 10-20 times higher than that ingested by the pups in the present study, who received the caffeine via the breast milk. In another study behavioral effects were observed in the offspring when mouse dams received more than $80 \mathrm{mg} / \mathrm{kg} / \mathrm{d}$ during pregnancy (6). In the present study the dose of caffeine given was low. It gives plasma concentrations in rat pups comparable to those seen in the umbilical cord plasma in newborns of moderately (up to 3 cups a day) coffee-drinking human mothers $(0.5-2 \mathrm{mg} / \mathrm{L})(42)$. The plasma levels of the pups also resembled the concentrations in breast-fed infants of caffeine-consuming mothers (43, 44).

Perinatal treatment with 6- to 12-fold higher doses of caffeine than those used here induces up-regulation of $A_{1}$ receptors in the postnatal and adult (P14-90) rat brain (19, 22, 23, 45). However, with the more relevant dosage used here little or no change in $A_{1}$ receptors was seen. We cannot exclude the possibility that there are some changes in some regions, but we can conclude that if they occur, they are small. In adult rodents there is good evidence that high doses of caffeine do produce increases in $\mathrm{A}_{1}$ receptors, that are not accompanied by changes in $A_{1}$ receptor mRNA (33). When lower doses are given no changes are observed, however. The present data considered together with the results of previous studies hence suggest that adaptive changes in adenosine $\mathrm{A}_{1}$ receptors are strongly dependent on the dose of caffeine given, not only in adults but also in young animals.

Thus, some of the reported long-term adaptive changes in behavior or in adenosine receptors may represent a high dose phenomenon. It is well known that the behavioral effects of caffeine, at least in mature animals, are biphasic: low doses are behaviorally stimulant, whereas higher doses produce an inhibited motor behavior (see Ref. 8). When caffeine is given in a low dose, it is unlikely that other receptors than adenosine $A_{1}$ and $\mathrm{A}_{2 \mathrm{~A}}$ receptors are directly affected (8). By contrast, higher doses can affect other targets including phosphodiesterases and benzodiazepine receptors.

The present results have confirmed that the primary targets for low-dose caffeine, i.e. the adenosine $\mathrm{A}_{1}$ and $\mathrm{A}_{2 \mathrm{~A}}$ receptors, are poorly developed in the immature rat brain. Beautiful studies on the prenatal development of mRNA of these receptors have already been published (9-11); however, the post- natal development of mRNA has not been studied in detail before. Both the absolute magnitude of the binding and the magnitude of the postnatal increase agree with a previous study on rat forebrain (24). Although $\mathrm{A}_{1}$ mRNA was present already on $\mathrm{E} 14$, and $\mathrm{A}_{1}$ receptor binding was apparent on $\mathrm{E} 18$ in agreement with previous studies $(9,10)$, the number of $A_{1}$ receptors is almost 10 times lower at birth than in the mature animal. Moreover, part of the binding detected at the earliest times might represent $\mathrm{A}_{2 \mathrm{~B}}$ receptors, because DPCPX has a high affinity also to these receptors (46). The development of $\mathrm{A}_{2 \mathrm{~A}}$ receptors has also been described $(10,12,47)$ using in situ hybridization and $\left[{ }^{3} \mathrm{H}\right]-\mathrm{CGS} 21680$ binding (but not $\left[{ }^{3} \mathrm{H}\right]-\mathrm{SCH}$ 58261 binding), and our results essentially agree with these extensive studies. However, although in the present study $\left[{ }^{3} \mathrm{H}\right]-\mathrm{CGS} 21680$ binding revealed $\mathrm{A}_{2 \mathrm{~A}}$ receptors on E21 in caudate putamen, nucleus accumbens, and olfactory tubercle, $\left[{ }^{3} \mathrm{H}\right]-\mathrm{SCH} 58261$ binding was not detected until P3. It is possible that part of the $\left[{ }^{3} \mathrm{H}\right]$-CGS 21680 binding reflects sites other than $\mathrm{A}_{2 \mathrm{~A}}$ receptors. Indeed, previous studies have shown that $\left[{ }^{3} \mathrm{H}\right]$-CGS 21680 may bind to other binding sites, especially in cerebral cortex and hippocampus, than the $\mathrm{A}_{2 \mathrm{~A}}$ receptor (48), whereas $\left[{ }^{3} \mathrm{H}\right]-\mathrm{SCH} 58261$ binds selectively to $\mathrm{A}_{2 \mathrm{~A}}$ receptors (30).

Although $\mathrm{A}_{1}$ and $\mathrm{A}_{2 \mathrm{~A}}$ receptors are present at birth in the rat (9-11), the major development in terms of density and coupling to second messenger-forming systems occurs postnatally $(12,13)$. This is highlighted in a difference between the present data and those of Rivkees in the magnitude of the increase in $A_{1}$ receptors from birth to adulthood. Whereas we found a 5to 10 -fold increase, Rivkees et al. reported a doubling (9). This might be explained by the fact that in the previous study GTP was not added to the binding assay and that, therefore, mainly $A_{1}$ receptors not coupled to G-proteins were detected. In our study, where GTP was added, both coupled and uncoupled receptors are detected, and in adult animals at least twice as many receptors are detected in the presence of GTP. This therefore suggests that in the immature brain few $A_{1}$ receptors are coupled to $\mathrm{G}$ proteins. Furthermore, we have other results using GTP $\gamma \mathrm{S}$ binding indicating that the $\mathrm{A}_{1}$ receptors that are present are poorly coupled to $\mathrm{G}$ proteins (Ådén U, unpublished observation).

Therefore, we believe that a reason for a lack of major effect on, for example, adenosine receptors in the brain of animals receiving low doses of caffeine pre- and postnatally is that the primary targets for caffeine action are poorly developed both in number and in coupling to effector proteins. It must be borne in mind that the situation may be different in tissues outside the brain. Indeed, there is evidence that the cardiac adenosine $\mathrm{A}_{1}$ receptors, for example, are well developed at birth (9). It is possible that maternal caffeine intake may affect other tissues than those studied here. It is also conceivable that effects on tissues outside the CNS may influence brain development.

The changes in benzodiazepine binding sites during early development were much less pronounced than in the case of the adenosine receptors. No significant up-regulation of $\left[{ }^{3} \mathrm{H}\right]$ flunitrazepam binding was seen after perinatal caffeine exposure, at least at the doses used in the present study. As noted above, previous studies on adult animals have given variable 
results. Again these may be related to the dose of caffeine inasmuch as direct effects of caffeine on benzodiazepine receptors require 40-100 times higher plasma concentrations than those observed here (see Ref. 8 for references). They are also higher than those measured in adults after normal human daily consumption of caffeine-containing beverages. Nonetheless, benzodiazepine receptors may be a target for high dose caffeine given perinatally.

In summary, the present results indicate that perinatal treatment with caffeine in doses that correspond to human consumption produces minimal changes in $A_{1}, A_{2 A}$, and $G_{A B A}$ receptors in cortex, hippocampus, striatum, and cerebellum. Although this is a negative finding it is potentially important because adaptive changes in these receptors have been linked to changes in the behavior of the offspring of coffee-consuming mothers. It is also suggested that the reason for the lack of effect is that in the immature brain the primary targets for caffeine given in low doses are poorly developed. Whereas the previous studies have raised concerns about maternal caffeine consumption, the present results may be reassuring for pregnant and breast-feeding human mothers who drink coffee in moderation.

Acknowledgments. We are grateful to Mrs. Karin Lindström for help with some of the autoradiographic experiments and to Professor Hugo Lagercrantz for critical advice on the manuscript.

\section{REFERENCES}

1. Olsen J, Overvad K, Frische G 1991 Coffee consumption, birthweight, and reproductive failures. Epidemiology 2:370-374

2. Purves D, Sutherland FM 1993 Caffeine, Coffee and Health. Raven Press, New York, pp 318-342

3. Furuhashi N, Sato S, Suzuki M, Hiruta M, Tanaka M, Takahashi T 1985 Effects of caffeine ingestion during pregnancy. Gynecol Obstet Invest 19:187-191

4. Godel JC, Pabst HF, Hodges PE, Johnson KE, Froese GJ, Joffres MR 1992 Smoking and caffeine and alcohol intake during pregnancy in a northern population: effect on fetal growth. CMAJ 147:181-188

5. Sobotka TJ, Spaid SL, Brodie RE 1979 Neurobehavioral teratology of caffeine exposure in rats. Neurotoxicology 1:403-416

6. Sinton CM, Valatx JL, Jouvet M 1981 Gestational caffeine modifies offspring behaviour in mice. Psychopharmacology 75:69-74

7. Holloway Jr WR 1982 Caffeine: effects of acute and chronic exposure on the behavior of neonatal rats. Neurobehav Toxicol Teratol 4:21-32

8. Fredholm BB, Battig K, Holmen J, Nehlig A, Zvartau EE 1999 Actions of caffeine in the brain with special reference to factors that contribute to its widespread use [Review] [571 refs]. Pharmacol Rev 51:83-133

9. Rivkees SA 1995 The ontogeny of cardiac and neural A1 adenosine recepto expression in rats. Brain Res Dev Brain Res 89:202-213

10. Weaver DR 1993 A2a adenosine receptor gene expression in developing rat brain. Brain Res Mol Brain Res 20:313-327

11. Weaver DR 1996 A1-adenosine receptor gene expression in fetal rat brain. Brain Res Dev Brain Res 94:205-223

12. Johansson B, Georgiev V, Fredholm BB 1997 Distribution and postnatal ontogeny of adenosine $\mathrm{A} 2 \mathrm{~A}$ receptors in rat brain: comparison with dopamine receptors. Neuroscience 80:1187-1207

13. Marangos PJ, Patel J, Stivers J 1982 Ontogeny of adenosine binding sites in rat forebrain and cerebellum. J Neurochem 39:267-270

14. Ferre S, Fuxe K, von Euler G, Johansson B, Fredholm BB 1992 Adenosine-dopamine interactions in the brain. [Review] [116 refs]. Neuroscience 51:501-512

15. Svenningsson P, Le Moine C, Fisone G, Fredholm BB 1999 Distribution, biochemistry and function of striatal adenosine A2A receptors. Prog Neurobiol 59:355-396

16. Baik JH, Picetti R, Saiardi A, Thiriet G, Dierich A, Depaulis A, Le Meur M, Borrelli E 1995 Parkinsonian-like locomotor impairment in mice lacking dopamine D2 receptors. Nature 377:424-428

17. Shi D, Nikodijevic O, Jacobson KA, Daly JW 1993 Chronic caffeine alters the density of adenosine, adrenergic, cholinergic, GABA, and serotonin receptors and calcium channels in mouse brain. Cell Mol Neurobiol 13:247-261
18. Wu PH, Phillis JW 1986 Up-regulation of brain [3H]diazepam binding sites in chronic caffeine treated rats. Gen Pharmacol 17:501-503

19. Boulenger JP, Patel J, Marangos PJ 1982 Effects of caffeine and theophylline on adenosine and benzodiazepine receptors in human brain. Neurosci Lett 30:161-166

20. Johansson B, Georgiev V, Kuosmanen T, Fredholm BB 1996 Long-term treatmen with some methylxanthines decreases the susceptibility to bicuculline- and pentylenetetrazol-induced seizures in mice. Relationship to c-fos expression and receptor binding. Eur J Neurosci 8:2447-2458

21. Lopez F, Miller LG, Greenblatt DJ, Kaplan GB, Shader RI 1989 Interaction of caffeine with the GABAA receptor complex: alterations in receptor function but not ligand binding. Eur J Pharmacol 172:453-459

22. Guillet R, Kellogg C 1991 Neonatal exposure to therapeutic caffeine alters the ontogeny of adenosine A1 receptors in brain of rats. Neuropharmacology 30:489-496

23. Etzel BA, Guillet R 1994 Effects of neonatal exposure to caffeine on adenosine A1 receptor ontogeny using autoradiography. Brain Res Dev Brain Res 82:223-230

24. Marangos PJ, Boulenger JP, Patel J 1984 Effects of chronic caffeine on brain adenosine receptors: regional and ontogenetic studies. Life Sci 34:899-907

25. Bona E, Aden U, Fredholm BB, Hagberg H 1995 The effect of long term caffeine treatment on hypoxic-ischemic brain damage in the neonate. Pediatr Res 38:312-318

26. Hagberg H, Bona E, Gilland E, Puka-Sundvall M 1997 Hypoxia-ischaemia model in the 7-day-old rat: possibilities and shortcomings. Acta Paediatr Suppl 422:85-88

27. Kaplan GB, Greenblatt DJ, Leduc BW, Thompson ML, Shader RI 1989 Relationship of plasma and brain concentrations of caffeine and metabolites to benzodiazepine receptor binding and locomotor activity. J Pharmacol Exp Ther 248:1078-1083

28. Fastbom J, Fredholm BB 1990 Effects of long-term theophylline treatment on adenosine A1-receptors in rat brain: autoradiographic evidence for increased receptor number and altered coupling to G-proteins. Brain Res 507:195-199

29. Parkinson FE, Fredholm BB 1990 Autoradiographic evidence for G-protein coupled A2-receptors in rat neostriatum using [3H]-CGS 21680 as a ligand. Naunyn Schmiedebergs Arch Pharmacol 342:85-89

30. Fredholm BB, Lindström K, Dionisotti S, Ongini E 1998 [3H]SCH 58261, a selective A2A adenosine receptor antagonist, is a useful ligand in autoradiographic studies. J Neurochem 70:1210-1216

31. Mahan LC, McVittie LD, Smyk-Randall EM, Nakata H, Monsma Jr FJ, Gerfen CR, Sibley DR 1991 Cloning and expression of an A1 adenosine receptor from rat brain. Mol Pharmacol 40:1-7

32. Schiffmann SN, Libert F, Vassart G, Dumont JE, Vanderhaeghen JJ 1990 A cloned $\mathrm{G}$ protein-coupled protein with a distribution restricted to striatal medium-sized neurons. Possible relationship with D1 dopamine receptor. Brain Res 519:333-337

33. Johansson B, Ahlberg S, van der Ploeg I, Brene S, Lindefors N, Persson H, Fredholm BB 1993 Effect of long term caffeine treatment on A1 and A2 adenosine receptor binding and on mRNA levels in rat brain. Naunyn Schmiedebergs Arch Pharmacol 347:407-414

34. Cunha RA, Johansson B, van der Ploeg I, Sebastiao AM, Ribeiro JA, Fredholm BB 1994 Evidence for functionally important adenosine A2a receptors in the rat hippocampus. Brain Res 649:208-216

35. Altman J, Bayer SA 1995 Atlas of Prenatal Rat Brain. CRC Press, Boca Raton, FL

36. Sherwood SN, Timiras PS 1970 A Stereotaxic Atlas of the Developing Brain. University of California Press, Berkeley, CA

37. Paxinos G, Watson C 1986 The Rat Brain in Stereotaxic Coordinates. Academic Press, Orlando, FL

38. Suzuki F, Shimada J, Mizumoto H, Karasawa A, Kubo K, Nonaka H, Ishii A, Kawakita T 1992 Adenosine A1 antagonists. 2. Structure-activity relationships on diuretic activities and protective effects against acute renal failure. J Med Chem 35:3066-3075

39. Fastbom J, Pazos A, Probst A, Palacios JM 1987 Adenosine A1 receptors in the human brain: a quantitative autoradiographic study. Neuroscience 22:827-839

40. Svenningsson P, Nomikos GG, Fredholm BB 1999 The stimulatory action and the development of tolerance to caffeine is associated with alterations in gene expression in specific brain regions. J Neurosci 19:4011-4022

41. Schlumpf M, Richards JG, Lichtensteiger W, Mohler H 1983 An autoradiographic study of the prenatal development of benzodiazepine-binding sites in rat brain. J Neurosci 3:1478-1487

42. Neims A, von Borstel RW 1983 Caffeine: metabolism and biochemical mechanisms of action. Nutr Brain 6:1-30

43. Ryu JE 1985 Caffeine in human milk and in serum of breast-fed infants. Dev Pharmacol Ther 8:329-337

44. Parsons WD, Neims AH 1981 Prolonged half-life of caffeine in healthy term newborn infants. J Pediat 98:640-641

45. Guillet R 1990 Neonatal caffeine exposure alters adenosine receptor control of locomotor activity in the developing rat. Dev Pharmacol Ther 15:94-100

46. Klotz KN, Hessling J, Hegler J, Owman C, Kull B, Fredholm BB, Lohse MJ 1998 Comparative pharmacology of human adenosine receptor subtypes - characterization of stably transfected receptors in CHO cells. Naunyn Schmiedebergs Arch Pharmacol 357:1-9

47. Schiffmann SN, Vanderhaeghen JJ 1992 Ontogeny of gene expression of adenosine A2 receptor in the striatum: early localization in the patch compartment. J Comp Neurol 317:117-128

48. Johansson B, Fredholm BB 1995 Further characterization of the binding of the adenosine receptor agonist [3H]CGS 21680 to rat brain using autoradiography. Neuropharmacology 34:393-403 